GA-A15575

\title{
THE NUCLEAR CLOSED-CYCLE GAS TURBINE (HTGR-GT) - DRY COOLED COMMERCIAL POWER PLANT STUDIES
}

\author{
by \\ COLIN F. MCDONALD and CHARLES R. BOLAND
}

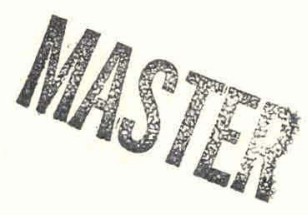

NOVEMBER 1979 


\section{DISCLAIMER}

This report was prepared as an account of work sponsored by an agency of the United States Government. Neither the United States Government nor any agency Thereof, nor any of their employees, makes any warranty, express or implied, or assumes any legal liability or responsibility for the accuracy, completeness, or usefulness of any information, apparatus, product, or process disclosed, or represents that its use would not infringe privately owned rights. Reference herein to any specific commercial product, process, or service by trade name, trademark, manufacturer, or otherwise does not necessarily constitute or imply its endorsement, recommendation, or favoring by the United States Government or any agency thereof. The views and opinions of authors expressed herein do not necessarily state or reflect those of the United States Government or any agency thereof. 


\section{DISCLAIMER}

Portions of this document may be illegible in electronic image products. Images are produced from the best available original document. 


\section{NOTICE}

This report was prepared as an account of work sponsored by the United States Government. Neither the United States nor the Department of Energy, nor any of their employees, nor any of their contractors, subcontractors, or their employees, makes any warranty, express or implied, or assumes any legal liability or responsibility for the accuracy, completeness or usefulness of any information, apparatus, product or process disclosed, or represents that its use would not infringe privately owned rights. 


\title{
GA-A15575
}

\section{THE NUCLEAR CLOSED-CYCLE GAS TURBINE (HTGR-GT) - DRY COOLED COMMERCIAL POWER PLANT STUDIES}

\author{
by \\ COLIN F. McDONALD and CHARLES R. BOLAND
}

This is a preprint of a paper to be presented at the 25th ASME International Gas Turbine Conference, March 9-13, 1980, New Orleans, Louisiana, and to be published as an ASME Paper.

\author{
Work supported by \\ Department of Energy \\ Contract DE-AT03-76SF70046
}

GENERAL ATOMIC PROJECT 6800 NOVEMBER 1979

\section{GENERAL ATOMIC COMPANY}




\title{
"THE NUCLEAR CLOSED-CYCLE GAS TURBINE \\ (HTGR-GT) - DRY COOLED COMMERCIAL \\ POWER PLANT STUDIES"! 1
}

$$
\text { by }
$$

Colin F. McDonald and Charles R. Boland Member ASME

\author{
General Atomic Company \\ San Diego, California
}

\begin{abstract}
Combining the modern and proven power conversion system of the closedcycle gas turbine (CCGT) with an advanced high-temperature gas-cooled reactor (HTGR) results in a power plant well suited to projected utility needs into the 21 st century. The gas turbine HTGR (HTGR-GT) power plant benefits are consistent with national energy goals, and the high power conversion efficiency potential satisfies increasingly important resource conservation demands. Established technology bases for the HTGR-GT are outlined, together with the extensive design and development program necessary to commercialize the nuclear CCGT plant for utility service in the 1990s. This paper outlines. the most recent design studies by General Atomic for a dry-cooled commercial plant of 800 to $1200 \mathrm{MW}(\mathrm{e})$ power, based on both non-intercooled and intercooled cycles, and discusses various primary systcm aspects. Details are given of the reactor turbine system (RTS) and on integrating the major power conversion components in the prestressed concrete reactor vessel.
\end{abstract}

${ }^{1}$ Work supported by U.S. Department of Energy Contract DE-AT03-76SF70046. 


\section{INTRODUCTION}

The advantages of the gas turbine high-temperature gas-cooled reactor exemplified many times in recent years (1-4), consist of the following: (1) plant simplification, (2) improved economics, and (3) siting flexibility. An extensive design and development program for the HTGR-GT components is necessary to commercialize the plant for utllity service in the last decade of this century. This paper discusses design aspects of the HTGR-GT plant in its present conceptual design stage and outlines the established technology bases for this new power plant concept. The existence of operating experience from both gas-cooled reactors and closed-cycle gas turbine (CCGT) power conversion systems makes the HTGR-GT plant a potential commercial reality for the late 1990s.

In the current period of energy consciousness. the utility companies are reviewing their nuclear capacity, including the important element of power plant rating. This paper reports on studies based on differing plant variants in the 800 to $1200 \mathrm{MW}(\mathrm{e})$

range. The multiloop power conversion system af fords flexibility toward future utility needs and increases plant avallability, since operation can be sustained with a loop shut down. Design studies for both nonintercooled and intercooled cycles are underway to maximize plant cost efficiency and resource conservation.

The excellent copencration capabilities of the Hrik-CT plant, made possible by the sensible heat rejection of the CCGT, have been well documented (5-7). However, it is the siting flexibillty of dry-cooled plants (covered in this report) that has attracted utility attention both in the U.S. and
Europe. Dry cooling relleves plant location from being tied to rivers and bodies of water that may well have already reached their assigned thermal effluent capacity. The HTGR-GT plant also takes advantage of limited cooling water via wet/dry cooling. For the sites with cooling water in the next century, it is prijected that botcoming cycle cogeneration will be available as an option to the utility owner. Compliance with nonproliferation guidelines and changing and more demanding safety considerations have had increasingly important 1 mpact on nuclear power plant design. The HTGR-GT plant is adaptable to high-, medium-, and low-enrichment fuel cycles. . This paper outlines power plant studies based on the medium-enriched uranium (MEU) fuel cycle, which are

thus in compliance with the current U.S. nonproliferation goals. A conservative design approach has been emphasized for the multiloop plant concept to provide for maximum safecy and durability. The HTGR is an Inherently safe reactor type by virtue of its graphite-moderated core, single-phase working fluld, and containment of all the nuclear equipment in a prestressed concrete reactor vessel (PCRV).

This paper reports only part of the rapidly increasing international efforts to combine the gas turbine and nuclear energy within the next two decades. The extraordinary role of the HTGR-GT in meeting international energy goals is significant. The studies reported in this paper represent an important step towards the selection of an optimized HTCR-CT plant configuration for the U.S. commercial marketplace.

\section{BACKGROUND OF HTGR-GT PLANT STUDIES}

As HTGR-GT plant design studies have progressed (since initiation in 1972), the thermodynamic cycle and plant configuration have evolved from investigations of the best means to satisfy the various performance, economic, safety, and operational goals. Many papers have been published in the open literature in the last seven years; a summary of the design evolution is given in Ref. (8). During this period, external assessments of the HTGR-GT plant have been 
carried out by the government and by spectalist consulting companies. From the technical and economic standpoints, these reviews have been favorable, as exemplified by the most recent assessment done by NUS Corporation under contract from Electric Power Research Institute (EPRI) (9).

An excenslve prugrañ of design, devclopment, and testing on the nuclear gas turbine plant is necessary to achieve performance and structural integrity and to qualify the equipment for nuclear power generation. This program is a main part of an international cooperative program currently underway. A dialogue has been in effect for several years between the U.S. program (General Atomic) and the European High Temperature Helium Turbine (HHT Project) partners. This effort intensified in 1977-78 relative to the definition of a European-sited demonstration plant. Such a demonstration plant is considered an attractive approach to creating the neressary technical base from which follow-on commercial plants could be engineered with a high degree of commonality for both $60 \mathrm{~Hz}$ United States and $50 \mathrm{~Hz}$ European power systems.

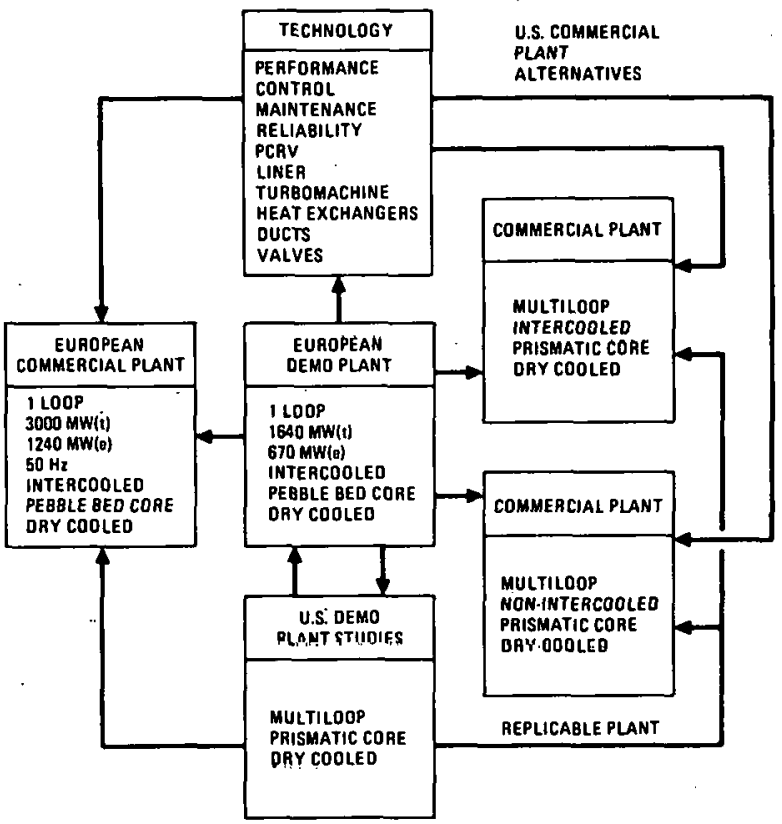

F1g. 1 Demonstration-commerclal plant relationsh1ps

Figure 1 presents qualitatively the relations between the U.S. plant studies, the European (HHT) demonstration project, and posstble U.S. and European follow-on commercial plants. Initial detalls of the HHT demonstration plant concept have been discussed previously $(10)$. The main features of the demonstration plant will be finalized in lace 1979, and an extensive international effort will be initiated to meet the goal of demonstration plant operation by about 1990. It is recognized that complete design convergence between the U.S. and European plant var1ancs is nut possible because of (1) the fundamental Érequency difference, (2) differing codes and standards, and (3) different safety and 11censing criter1a. It is further recognized, however, that commonality in the main features of the plants, together with a strong technology exchange effort, would be a move in the direction of minimizing overall cost and lowering development risks, by utilizing worldwide technology.

Work on the HTGR-GT plant over the last few years has been supported by the U.S. Department of Energy and a group of electrical utilities, with participation by industrial companies. A key element in the formulation of a new power plant concept is participation by utility organizations right from the onset, and Indeed, such a rapport has been. in existence on the HTGR-CT program since 1972. With the formation of the Gas Cooled Reactor Associates (GCRA), the ut1lity inputs to plant design are now more formalized. With regular meetings of the GCRA Technical Advisory Committee (TAC), the utility directives can be factored into the plant design on an on-going basis right from the conceptual design stage.

Unt1l recently, work in the U.S. at General Atomic had been directed towards the design, performance, and economic assessment of a HTGR-GT plant in the 1200-MW(e) class with capability of being adapted to both smaller and larger units. A 1200-MW(e) reference plant established in 1977-78, based on a nonIntercooled cycle and embodying three power conversion loops (PCLs), has been described previously (11).

Over the last few years, plant layout studies have been done for a wide range of power levels. These studies have consisted essentially of varying the number of PCLs, sizing the major components, evaluating the impact of component orientation on PCRV diameter, computing plant efficiency, and estimating costs (capital and power generating costs). The range of plants studied in a conceptual manner and the impact on PCRV diameter (which is regarded as a majoi capital cost indicator) are shown on Fig. 2 .

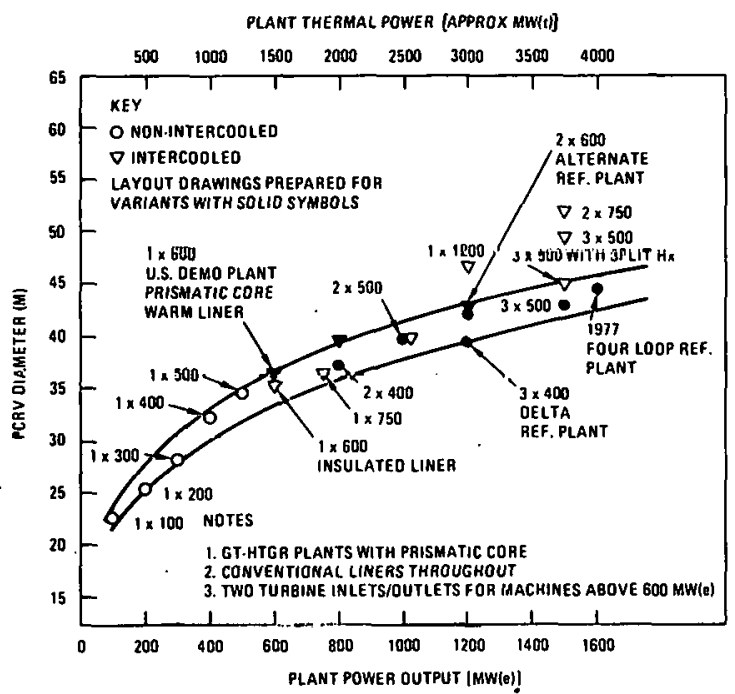

F1g. 2 Impact of HTGR-GT plant power rating on PCRV diameter

Inputs from TAC indicate a trend away from the larger plants envisioned a few years ago for operation towards the end of this century. Studies are now aimed at plants in the range of 800 to 1200 MW(e), and this paper out lines configurations in this range based on both non-intercooled and interronled cyrless and with differing numbers of PCLs. 


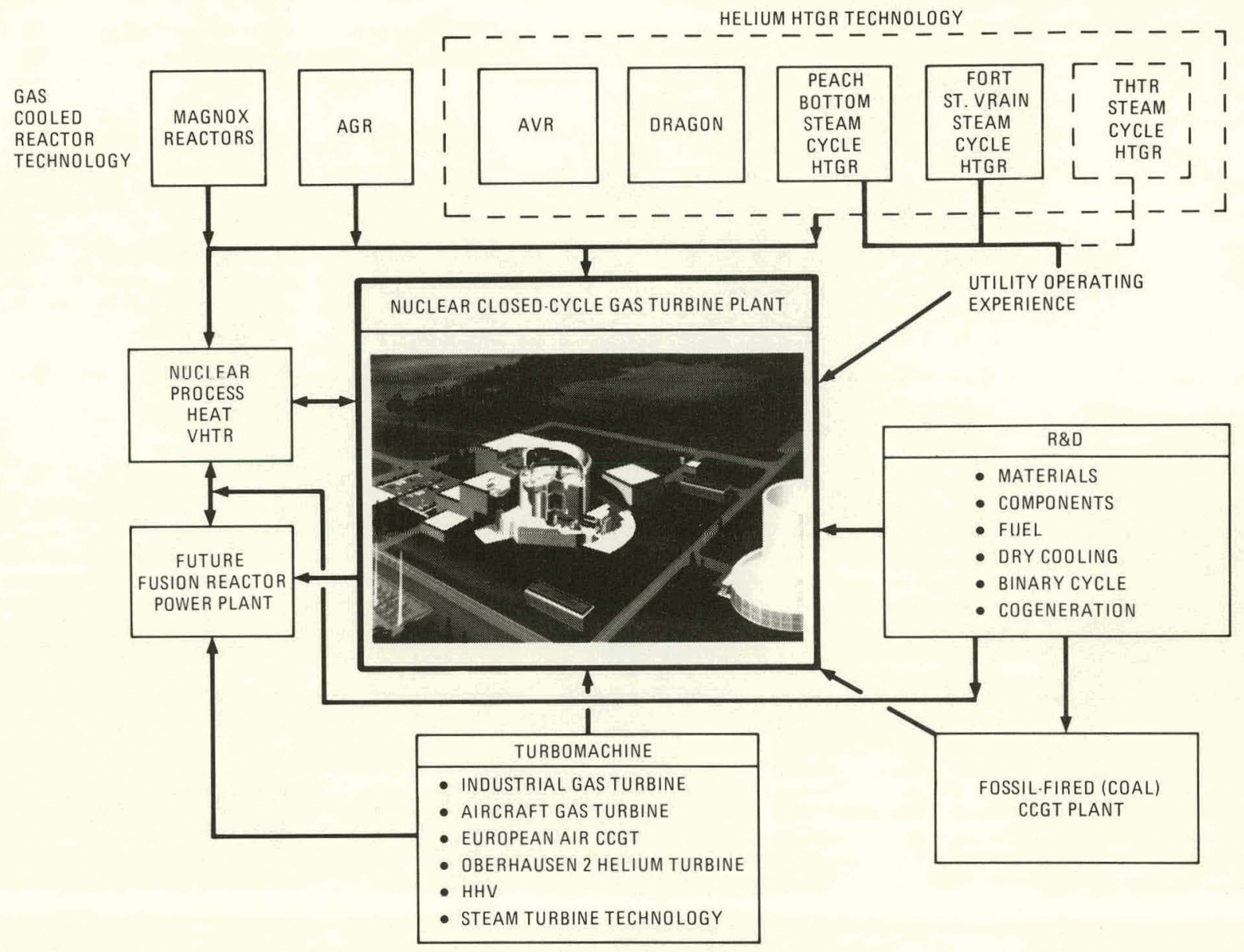

Fig. 3 Technology bases for HTGR-GT plant

TECHNOLOGY BASES FOR HTGR-GT PLANT

The technology resources from which the HTGR-GT plant can draw are formidable and are briefly outlined in this section. The necessary technologies stem from several sources, as shown in Fig. 3, and when combined, form the bases from which a successful nuclear gas turbine plant can be designed, developed, and introduced into utility service with a high degree of confidence that the performance, economic, safety, and reliability goals will be realized.

From the reactor standpoint, there is extensive operating experience for gas-cooled reactors, and in particular, for the helium-cooled high temperature reactor. Valuable pioneering experience from the experimental high temperature reactors in the United Kingdom (Dragon Project), in the U.S. (UHTREX), and in the Federal Republic of Germany (AVR) formed the basis for the first HTGRs entering commercial service: the Peach Bottom and Fort St. Vrain reactors in the U.S. and (in the near future) the THTR plant in Germany. These HTGRs, while based on a steam-cycle power conversion system, provide valuable utility operating experience input to the HTGR-GT program.

While the CCGT is not well known in the U.S., it has demonstrated very high fuel utilization efficien- cies and a high degree of reliability in the various European plants. Since operation of the pioneer plant in 1939 , the 40 years of experience have substantiated the claim that this prime-mover technology is well established (12). With the helium turbomachine itself being the singularly most important PCL component from the development standpoint, the applicability of established technologies from (1) European CCGT plants, (2) helium test facilities, (3) HTGR components and steam-cycle plant operating experience, and (4) advanced open-cycle industrial gas turbines are recognized. The industrial technology bases from which the turbomachine can benefit are shown on Fig. 4, which illustrates existing hardware. The emphasis here relates to the available comprehensive world-wide resources, which if utilized on an international cooperative

basis, will make near-term introduction of the nuclear gas-turbine plant a reality.

An important helium turbine plant is the fossilfired $50 \mathrm{MW}(\mathrm{e})$ Oberhausen 2 unit which was built by Energieversorgung Oberhausen AG (EVO) in the Federal Republic of Germany. Many reports and papers have been written describing the EVO plant construction and operation (13-15). In addition to providing electrical power $[50 \mathrm{MW}(\mathrm{e})]$ and district heating

$[54 \mathrm{MW}(\mathrm{t})]$, the tests carried out on the EVO plant are 


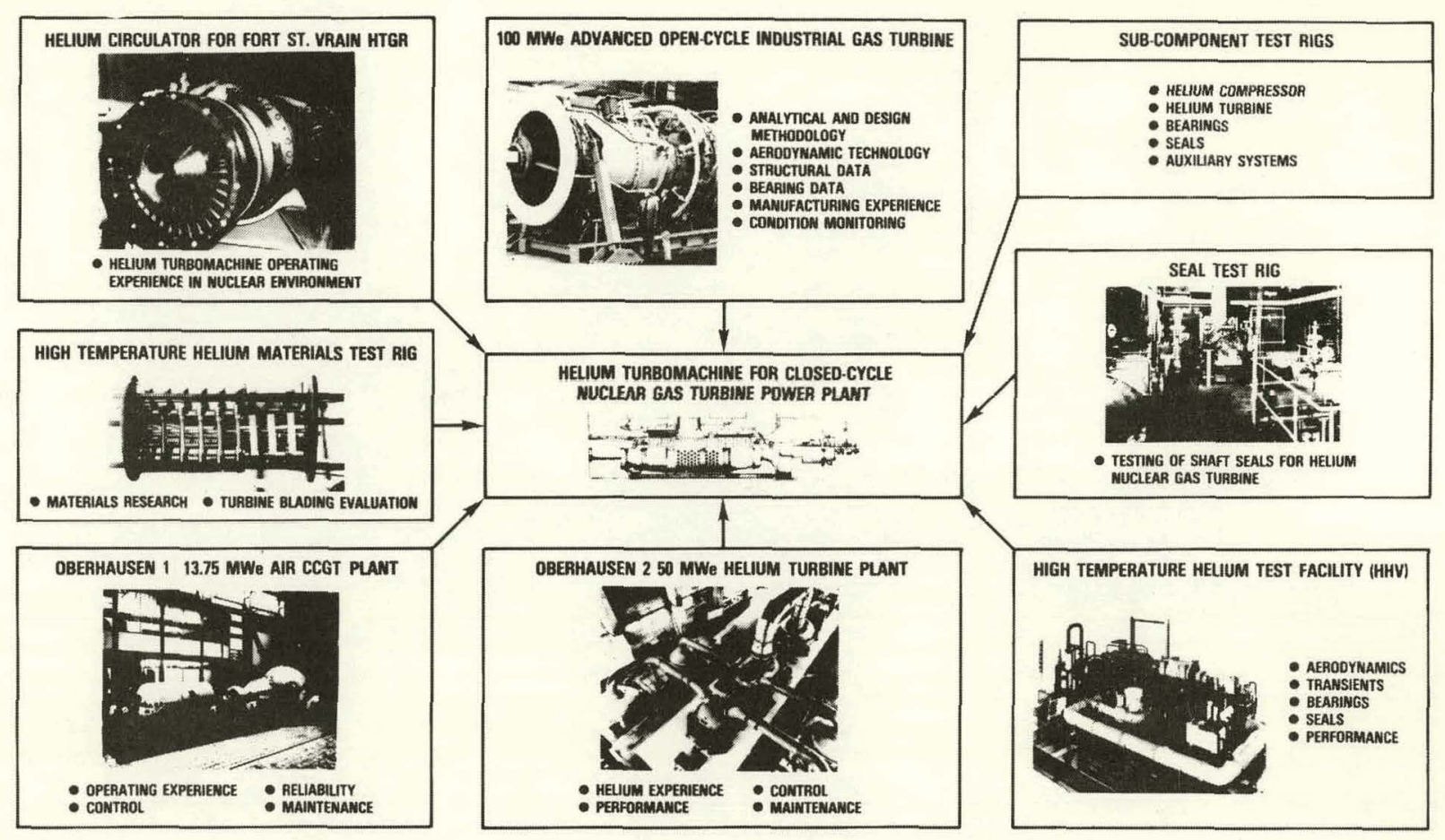

Fig. 4 Technology bases for nuclear closed-cycle helium turbomachine

intended to supply information (for the nuclear gasturbine program) on the dynamics of the overall plant and on the long-term behavior of specific components. Another important plant is the high temperature helium test facility (HHV) at the Kernforschungsanlage (KFA) in Julich. The operation of this helium test plant represents a central test within the European HHT project. By this program, essential characteristics of the turbomachine are to be verified. Furthermore, this plant serves for tests of prototype components for the HHT demonstration plant. A full account is given in Ref. (16) of the roles of the EVo plant and HHV test facility in the development of the European HHT project.

Emphasis of the formidable technology bases for the HTGR-GI plant has been made in this section of the paper, because this adds credibility to the claim that a new power plant type such as the HTGR-GT, while now only in the conceptual design stage, could become a commercial reality for utility service by the year 2000 .

\section{THERMODYNAMIC CYCLE(S) AND PERFORMANCE}

A detailed account of the systems-related studies leading to the selection of an optimized set of cycle parameters is reported in a separate paper (17), so only a brief summary of the impact these have on plant layout and design will be covered here. In the HTGR-GI plant studies done over the last few years by General Atomic, there has been a strong motivation to use the non-intercooled cycle for the following reasons: (1) plant simplicity in both turbomachine and primary system and (2) high reject temperature for economical dry cooling and optional bottoming cycle. In Europe, on the other hand, the intercooled cycle has always been favored because
(1) it has higher efficiency, (2) the reject water temperature is well suited to district heating, and (3) there is a carry-over from the European fossilfired CCGT plants, which have all been intercooled. In any compression process involving a multistage system, cooling between the stages reduces the compression work, and in the case of the CCGT, the plant efficiency is increased by virtue of the higher net turbine output. On a purely thermodynamic basis, an increase of about 3 percentage points can be computed for the intercooled cycle. When the additional pressure losses in the intercooler and in the more complex ducting arrangement are taken into account, the gain in efficiency is reduced to about 2 percentage points. Nevertheless, such a gain over the $40-$ year operating life of the plant has significant economic implications, and hence, the current study of plant designs is based on both intercooled and non-intercooled cycles. Some of the major factors involved in the issue of intercooling versus nonintercooling are outlined on Table 1.

As mentioned previously, efforts are underway for both plant variants to select the cycle parameters for minimum power generating cost. For the purpose of component sizing and plant configuration layout studies, it was necessary to establish early comparative cycle data. The tentative values used are shown on Table 2 , and these data are felt to be very representative for design purposes. The key differences between the two cycles are shown on the loop diagram for the non-intercooled plant (Fig. 5) and on the flowpath diagram for the intercooled variant (Fig, 6).

An important parameter influencing the efficiency of the closed-cycle plant is the turbine inlet temperature. For the power plant studies outlined in this paper, a turbine inlet temperature of $850^{\circ} \mathrm{C}$ has been assumed. This temperature is modest 
TABLE

MAJOR FACTORS RELATING TO THE ISSUE OF INTERCOOLING

Non-intercooled Plant

1. Simpler turbomachine (shorter rotor, less duct connections)

2. Simpler gas flow paths and primary system layout

3. Less complex system implies improved availability and reliability

4. High reject temperature well suited for cogeneration (i.e., binary cycle, process steam, district heating, etc.)

5. Reduced plant construction time (simpler PCRV)

6. Reduced complexity and risk

Intercooled Plant

1. Increased cycle thermodynamic efficiency

2. Reduced helium mass flow rate (i.e., smaller components)

3. Source of cooler high-pressure gas available for cavity liner cooling

4. Reduced core inlet gas temperature

5. Possible use of additional water-to-helium heat exchanger (intercooler) for decay heat removal

6. Heat rejection split between two water-to-helium exchangers (precooler and intercooler) results in smaller unit assemblies

7. Utilization of European experience from the small fossil-fired CCGTs

8. Water outlet temperature well suited for district heating

9. Additional maintenance requirements

10. Increased plant capital cost

11. Additional potential source of water ingress to primary system

TABLE 2

HTGR-GT CYCLE DATA USED IN PLANT CONFIGURATION COMPARISON STUDIES

\begin{tabular}{|c|c|c|}
\hline Thermodynamic Cycle & Non-intercooled & Intercooled \\
\hline $\begin{array}{l}\text { Heat rejection mode } \\
\text { Turbine inlet } \\
\text { temp, }{ }^{\circ} \mathrm{C}\end{array}$ & $\begin{array}{l}\text { Dry-cooled } \\
850\end{array}$ & $\begin{array}{l}\text { Dry-cooled } \\
850\end{array}$ \\
\hline $\begin{array}{l}\text { Ambient air temp, } \\
{ }^{\circ} \mathrm{C}\end{array}$ & 15 & 15 \\
\hline $\begin{array}{l}\text { Compressor inlet } \\
\text { temp, }{ }^{\circ} \mathrm{C}\end{array}$ & 26.7 & 26.7 \\
\hline $\begin{array}{l}\text { Max system pressure, } \\
\mathrm{MPa}\end{array}$ & 7.93 & 7.93 \\
\hline $\begin{array}{l}\text { Compressor pressure } \\
\text { ratio }\end{array}$ & 2.50 & $\begin{array}{c}3.0 \\
(1.73 / 1.73)\end{array}$ \\
\hline $\begin{array}{l}\text { System pressure loss } \\
\qquad(\triangle P / P), \%\end{array}$ & $\sim 9$ & $\sim 11$ \\
\hline $\begin{array}{l}\text { Compressor flow } \\
\mathrm{kg} / \mathrm{s} / \mathrm{MW}(\mathrm{t})\end{array}$ & 0.57 & 0.50 \\
\hline $\begin{array}{l}\text { Recuperator } \\
\text { effectiveness }\end{array}$ & 0.90 & 0.90 \\
\hline $\begin{array}{l}\text { Compressor } \\
\text { efficiency, } \%\end{array}$ & 89.8 & $\begin{array}{l}90.8 \mathrm{LP}, \\
90.2 \mathrm{HP}\end{array}$ \\
\hline Turbine efficiency, \% & 91.8 & 92.2 \\
\hline $\begin{array}{l}\text { Precooler water } \\
\text { outlet temp, }{ }^{\circ} \mathrm{C}\end{array}$ & 132 & 87 \\
\hline $\begin{array}{c}\text { Intercooler water } \\
\text { outlet temp, }{ }^{\circ} \mathrm{C}\end{array}$ & -- & 66 \\
\hline Cycle efficiency, \% & 240.0 & $242.0^{\circ}$ \\
\hline
\end{tabular}

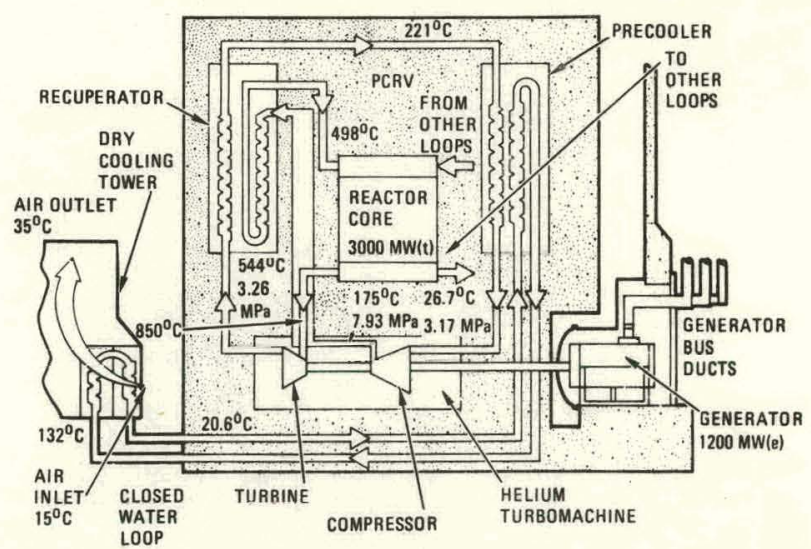

Fig. 5 Loop cycle diagram for non-intercooled drycooled HTGR-GT power plant

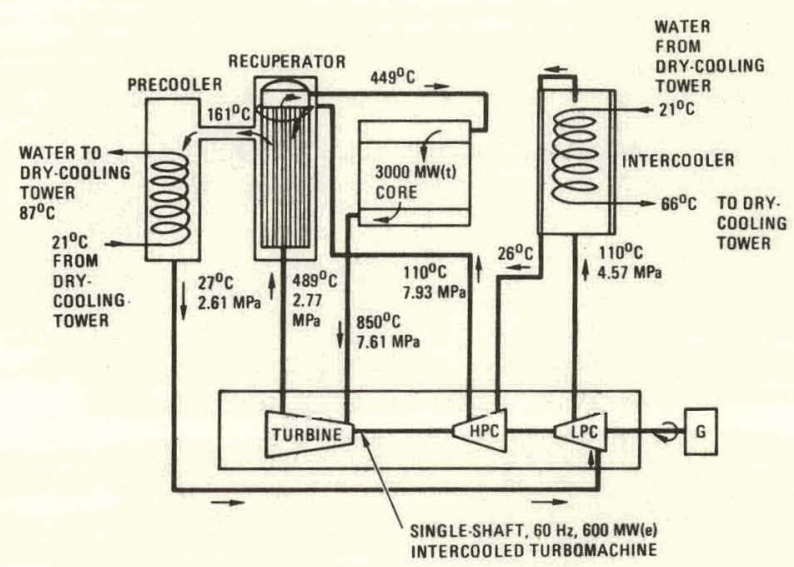

Fig.6 Flow path diagram for two-loop intercooled HTGR-GT plant

compared to that for most industrial gas turbine practice (18); it is below the level where turbine blade cooling is necessary, and it facilitates utilization of an existing nicke1-base alloy which is used extensively in industrial gas turbines. The impact of turbine inlet temperature, together with other important parameters, is shown on Fig. 7 for a non-intercooled cycle. Projected operating regimes for various CCGT plant applications are shown on this plot. It is clear from Fig. 7 that the CCGT offers significant potential for high levels of plant efficiency when dry cooled.

PLANT CONFIGURATION STUDIES

Three-Loop, 1200-MW(e) Non-Intercooled Plant Concept As previously mentioned, this $1200-\mathrm{MW}(\mathrm{e})$ plant variant has received the most design attention in recent years, and $I_{n}$ terms of performance and cost, forms the base case for comparison with other plant concepts. An isometric view given on Fig. 8 shows the major elements of the power conversion system integrated inside the PCRV. The compact nature of the installation is shown on the plan view of the PCRV (Fig. 9). An obvious goal in all plant design and layout studies is the minimization of the PCRV 


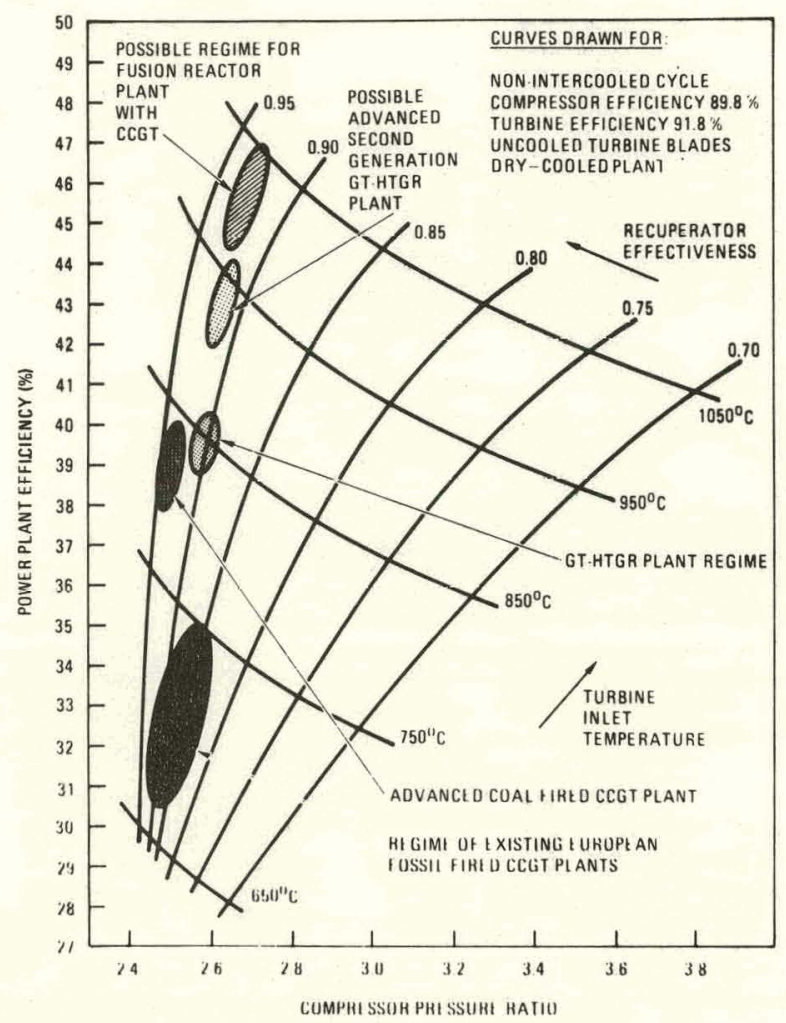

Fig.7 Representarive cycle parameter array for nonintercooled HTGR-GT plant

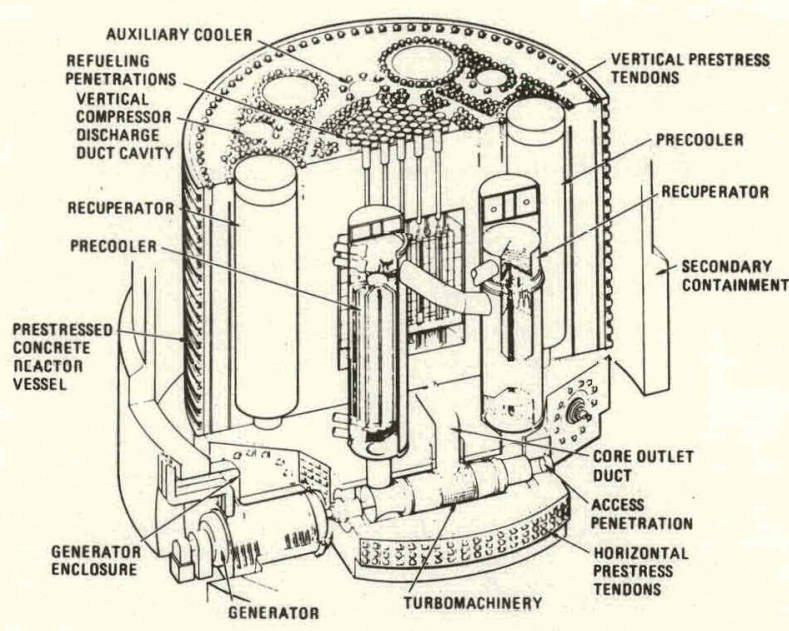

Fig. 8 Integrated HTGR-GT plant based on 3 PCLs and non-intercooled cycle

diameter because of its economic impact. The arrangement shown on Fig. 9 has the following main features: (1) centralized core cavity, (2) delta orientation of the three turbomachines, and (3) recuperator and precooler positioned over the turbomachine cavity. This arrangement represents a very good utilization of space within the reactor vessel, and in fact, satisfies the economic goal of PCRV diameter minimization.

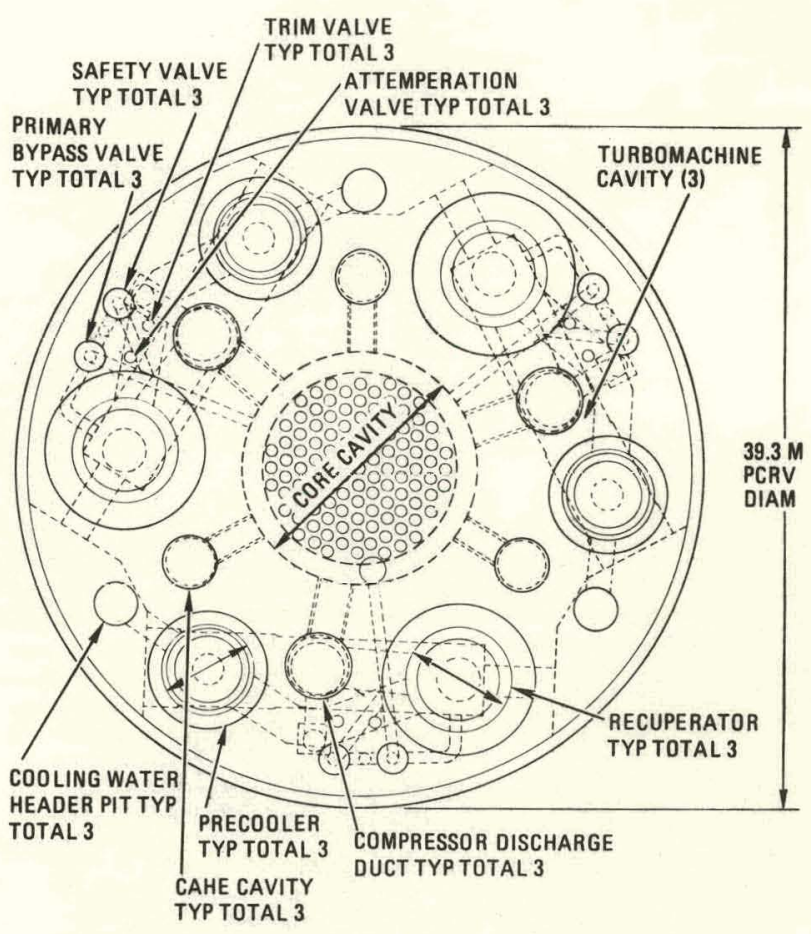

Fig.9 PCRV plan view for $3 \times 400-M W(e)$ nonintercooled HTGR-GT plant

The delta orientation of the PCLs, as shown on Fig. 9, is well suited to the non-intercooled cycle. Incorporation of intercoolers is not attractive in this three-loop arrangement, since they must be positioned radially outwards from the turbomachine cavity, and this results in an unacceptably large increase in PCRV diameter. As will be outlined in the following sections, evaluation of the intercooled cycle is being done for two-loop plant variants.

Two-Loop, 1200-MW(e) Intercooled Plant Concepts The motivations for the study of a two-loop plant included the following: (1) potential capital cost reduction, (2) flexibility in power range, (3) adaptability to intercooling, (4) maximization of Lecluical finterchange between U.S. and European programs, and (5) simplified turbomachine maintenance. Accordingly, studies in the last year have involved the conceptual design and layout of two-loop plant variants based on both intercooled and non-intercooled cycles.

A representative layout of a two-loop intercooled plant is shown on the PCRV plan view given on Fig. 10. While studies have been performed for PCL ratings of 400 , 500, and $600 \mathrm{MW}(\mathrm{e})$, the main features of the plant are essentially the same, and the view shown on Fig. 10 for a 2 x $600 \mathrm{MW}(\mathrm{e})$ concept can be considered representative. Again, as in previous studies, efforts were expended to minimize the diameter of the PCRV, and this was achieved by a combination of the following: (1) offsetting the core cavity, (2) chordal positioning of the two horizontal turbomachine cavities, (3) positioning the recuperator and precooler over the turbomachine cavity, and (4) establishing simplified gas flow paths within the primary system. Layout studies led to the positioning of the two intercoolers and three decay heat removal systems, 


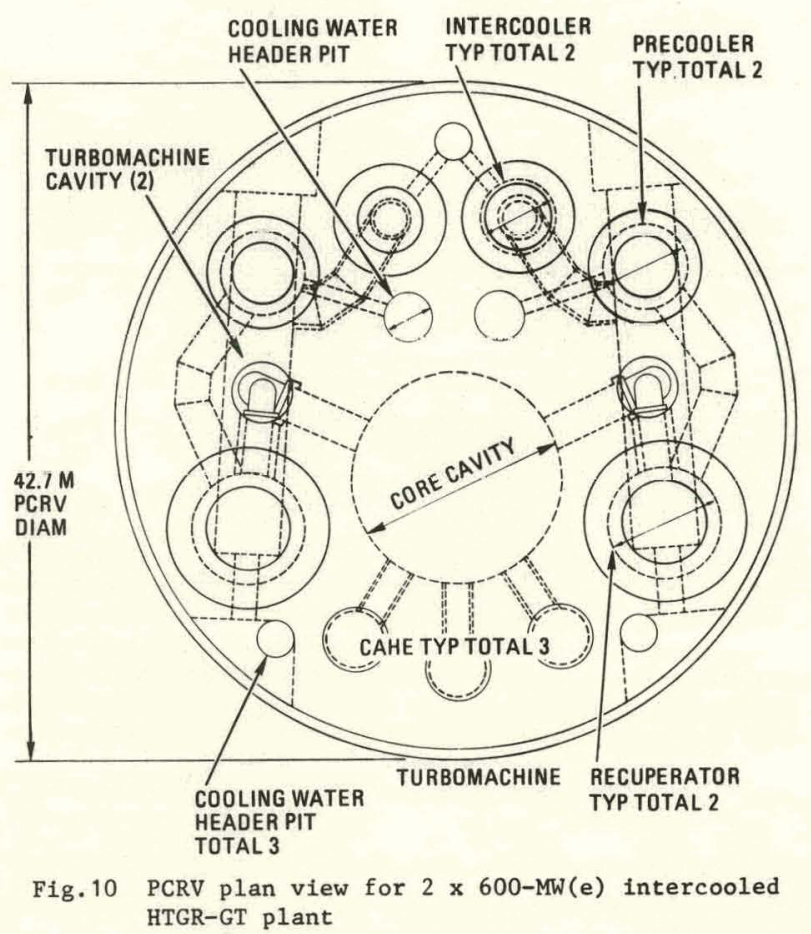

as shown on Fig. 10, to give an acceptable arrangement from the standpoints of gas flow paths and PCRV structural considerations. It is recognized that with more in-depth studies the positioning of the major components within the vessel (and the angle of the turbomachine cavities) may change; however, the general arrangement shown on Fig. 10 is regarded as the optimum for a two-loop intercooled plant. The elevation view through the PCRV on Fig. 11 shows the simple gas flow paths between the turbomachine and the heat exchangers (it should be noted that the intercooler is not shown in this particular sectional view). The gas flow paths to and from the reactor core cavity are shown on Fig. 12. Also shown on this figure is a section through the core auxiliary cooling system (CACS), and the gas flow paths to and from the core cavity and in the heat exchanger and circulator can be clearly seen.

Two-Loop Non-Intercooled Plant Concepts

As part of the study to compare the designs, economics, performance, and availability of intercooled versus non-intercooled plants, a layout study was performed to identify the main features of a twoloop non-intercooled plant variant.

A representative layout of a two-loop nonintercooled plant is shown on the PCRV plan view given on Fig. 13. While studies have been performed for PCL ratings of 400,500 , and $600 \mathrm{MW}(\mathrm{e})$, the main features of the plant are essentially the same, and the view shown on Fid 13 for a $2 \times 500 \mathrm{MW}($ E) concept can be considered representative. Several layout variants were developed for the non-intercooled plant, and the one shown on Fig. 13 has the following characteristics: (1) centralized core cavity, (2) chordal turbomachine cavity orientation, and (3) recuperator and precooler positioned over the turbomachine cavity. The positioning of the three CACS units (in a different orientation from the aforementioned intercooled variant)

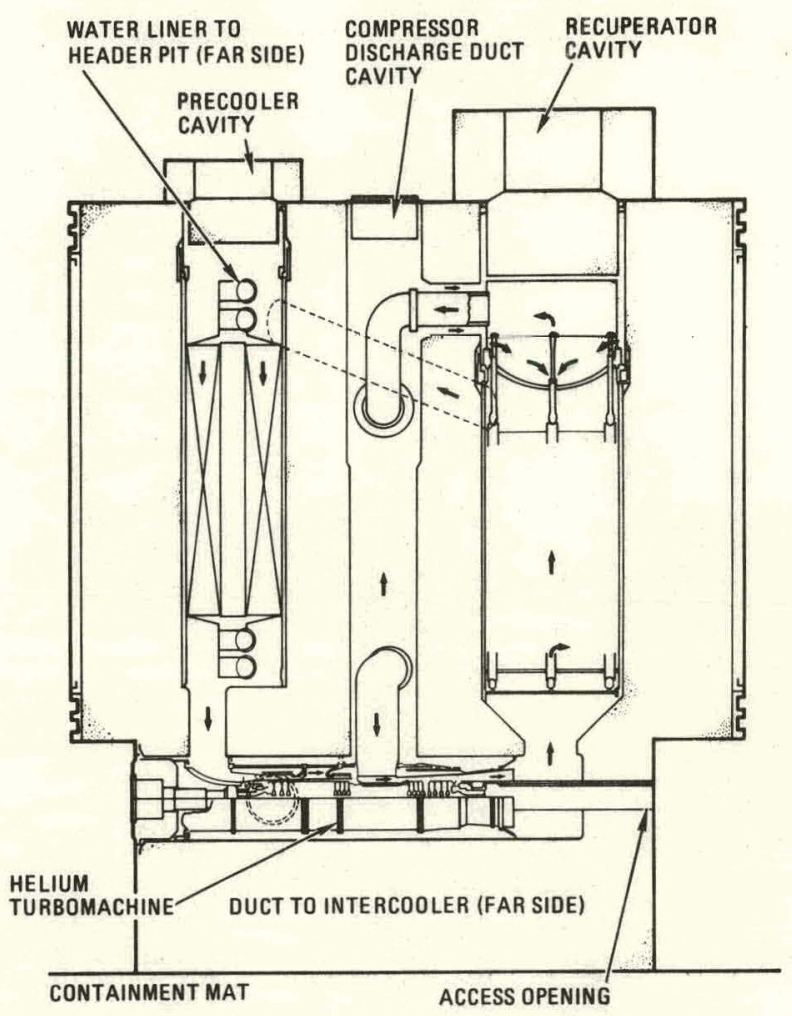

Fig. 11 View through PCL for two-loop HTGR-GT plant

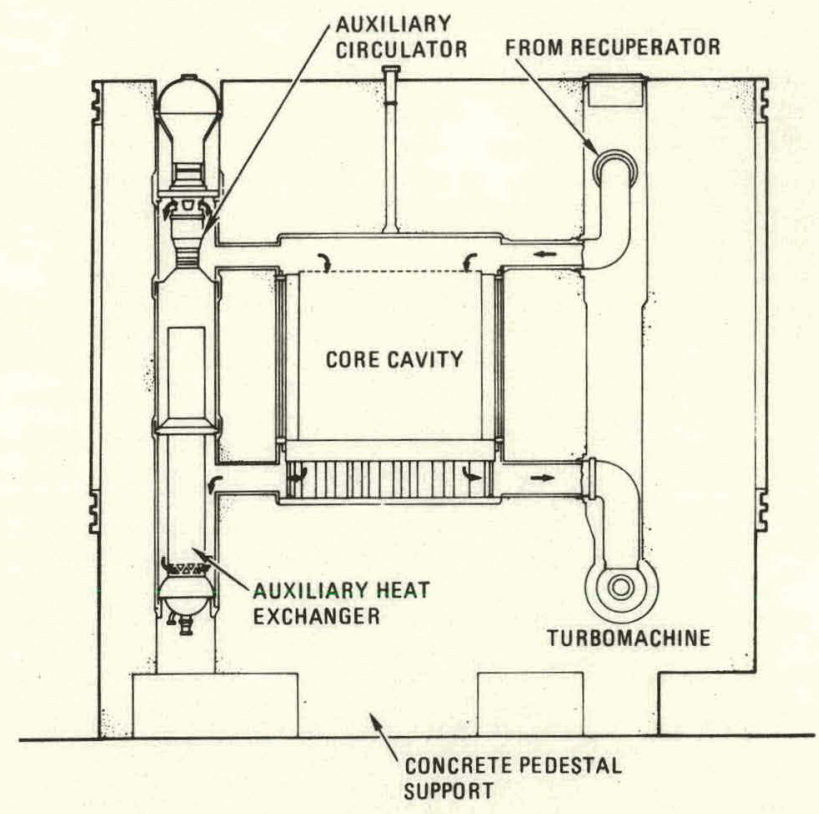

Fig.12 Elevation through PCRV showing core cavity and decay heat removal system 


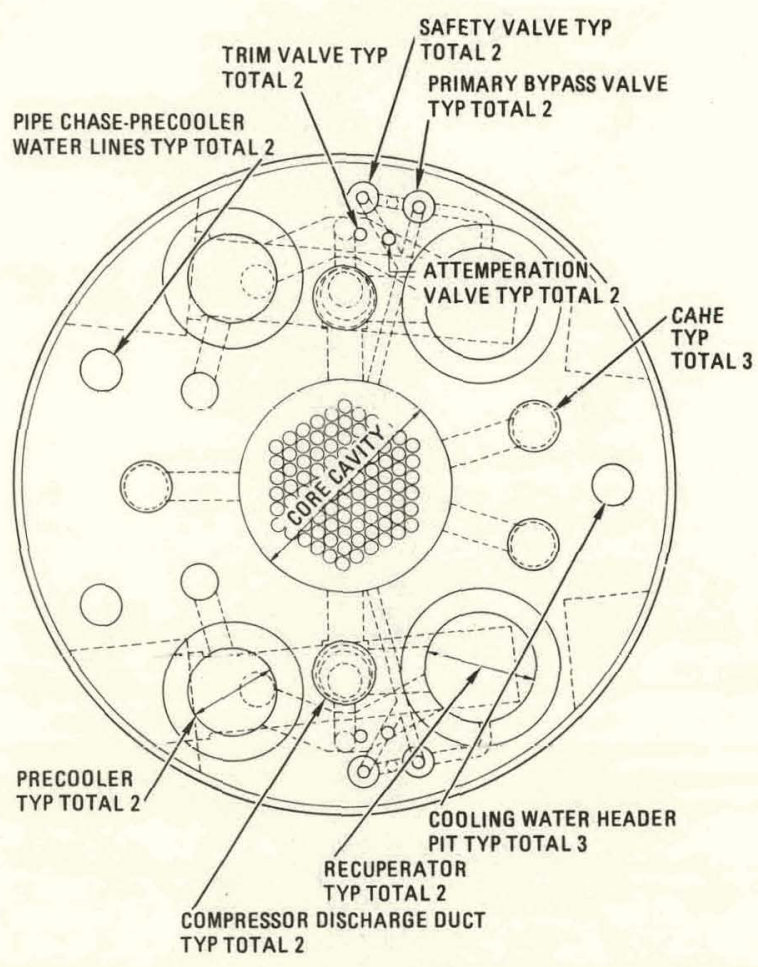

Fig.13 Plan view of PCRV for 2 x 500-MW(e) nonintercooled HTGR-GT plant

is conducive to good gas flow paths, PCRV structural considerations, and minimization of the vessel diameter. The main characteristics of the elevation views through the PCRV (shown previously for the intercooled variant on Figs. 11 and 12) are near identical for the two-loop non-intercooled plant.

\section{Summary of Plant Layout Studies}

Two major decisions in the HTGR-GT program will be made in 1979: (1) the power plant rating, and (2) the issue of intercooling versus nonintercooling. As will be mentioned in the following sections, a decision has been made to proceed with a plant embodying two PCLs. The plant layout studies presented in this paper are in support of the overall evaluation that will lead to the selection of a new reference plant concept.

As shown on Fig. 2, design studies have been performed for a wide range of plant variants. However, the most recent work done (and reported in this paper) has centered on (1) two- and three-loop concepts, and (2) PCL ratings of 400,500 , and $600 \mathrm{MW}(\mathrm{e})$. A summary of the salient features of some of the plant concepts studied is given on Table 3 . The main disadvantages of the three-loop plant are (1) inflexibility of power rating [i.e., it is better suited to plants of $1200 \mathrm{MW}(\mathrm{e})$ and higher], (2) not attractive as an intercooled variant (i.e., complex gas flow paths and large PCRV diameter), (3) high capital cost associated with the large number of components, and (4) an operational problem exists in that the generator must be moved before a turbomachine can be replaced.

From Table 3 and the layout concepts presented, it can be observed that the two-loop plant offers a simplified PCRV arrangement and has rating flexibility in the range of 800 to $1200 \mathrm{MW}(\mathrm{e})$. It is also significant that an intercooler can be embodied without a major impact on PCRV diameter. The motivations for utilization of a two-loop plant layout concept are given on Table 4 .

\section{COMPONENT DESIGN CONSIDERATIONS}

It is not the purpose of this paper to describe in detail the design considerations for the major components of the HTGR-GT plant, since as noted below, these have been reported previously. However, for an integrated plant, the PCL components cannot be treated as isolated units, and indeed, their design and the resolution of the interconnecting gas flow path geometries must be considered during the establishment of the plant primary system configurations. During the aforementioned primary system design studies, extensive layout work was done to identify the most attractive installation and orientation of the major components. The main PCL components which have a strong influence on the primary system design are the turbomachine and the heat exchangers, and brief descriptions of these are given below.

\section{Helium Turbomachine}

The most recent turbomachinery design work for the HTGR-GT power plant has been done by the Power Systems Division and Pratt and Whitney Aircraft Division of United Technologies Corporation (UTC). General Electric and Brown Boveri Company were earlier participants in the HTGR-GT program. Since details of the helium turbomachine have been described previously (18-21), only a very brief summary will be given in this paper.

In support of the plant configuration studies, turbomachine conceptual designs were done for machines in the 400,500, and $600 \mathrm{MW}(\mathrm{e})$ power classes for both intercooled and non-intercooled types. To span the above power range and to illustrate the difference between the machine types, only the $400 \mathrm{MW}(\mathrm{e})$ (nonintercooled) and $600 \mathrm{MW}(\mathrm{e})$ (intercooled) variants will be addressed in this paper. Details of the 400 and $600 \mathrm{MW}(\mathrm{e})$ turbomachines are shown on Figs. 14 and 15, respectively, and the salient features are summarized on Table 5. As will be discussed below, the two machines embody similar features in many areas. The design and performance predictions for these machines reflect the influence of technology from a demonstrated advanced technology industrial gas turbine in the 70 to $100 \mathrm{MW}(\mathrm{e})$ power size (22).

An extremely simple arrangement consisting of a single-shaft direct-drive arrangement was chosen for both machines. The use of a two bearing rotor, feasibility of which has been confirmed by rotor dynamic analyses to ensure adequate critical speed margin, maintained the smallest number of individual parts and tended to minimize the overall cost of the machine, and to ease inspection and maintenance requirements.

Aerothermodynamic analysis showed that for both the 400 and $600 \mathrm{MW}(\mathrm{e})$ machines a single turbine inlet duct (from the reactor) could be utilized, and the pressure losses and flow inlet geometry to the turbine bladed section were satisfactory. In the plant layout studies, it was found that a key element (from the standpoint of effective PCRV volume utilization) is the embodiment of a turbomachine with a single turbine inlet duct. For machine sizes above $700 \mathrm{MW}(\mathrm{e})$, studies have shown the need for two turbine inlet ducts; for a plant embodying two such gas turbines, the gas flow paths are unduly complex, and the PCRV diameter is excessive. 
TABLE 3

COMPARISON OF HTGR-GT PLANT CONCEPTUAL DESIGNS

\begin{tabular}{|c|c|c|c|c|c|}
\hline $\begin{array}{l}\text { Loop Rating, } \\
\text { (MW(e) }\end{array}$ & \multicolumn{2}{|c|}{400} & 500 & 600 & 400 \\
\hline $\begin{array}{l}\text { Thermodynamic } \\
\text { cycle } \\
\text { No. of loops } \\
\text { Plant output, } \\
\text { MW(e) }\end{array}$ & $\begin{array}{l}\text { Non- } \\
\text { intercooled } \\
2 \\
800\end{array}$ & $\begin{array}{l}\text { Intercooled } \\
\qquad \begin{array}{l}2 \\
800\end{array}\end{array}$ & $\begin{array}{l}\text { Non- } \\
\text { intercooled } \\
2 \\
1000\end{array}$ & $\begin{array}{l}\text { Intercooled } \\
\qquad \begin{array}{l}2 \\
1200\end{array}\end{array}$ & $\begin{array}{c}\text { Non- } \\
\text { intercooled } \\
3 \\
1200\end{array}$ \\
\hline $\begin{array}{l}\text { Plant eff1- } \\
\text { ciency, \% }\end{array}$ & 240.0 & $\sim 42.0$ & $\sim 40.0$ & $\sim 42.0$ & $\sim 40.0$ \\
\hline Core rating, & 2000 & 1905 & 2500 & 2860 & 3000 \\
\hline $\begin{array}{l}\text { Plant type } \\
\text { Heat rejection } \\
\text { Liner type } \\
\text { Core type } \\
\text { Fuel type } \\
\text { Fuel cycle, yr } \\
\text { Core power den- }\end{array}$ & \multicolumn{5}{|c|}{$\begin{array}{c}\text { Power conversion system integrated in PCRV } \\
\text { Dry-cooled } \\
\text { Conventional, insulated, and water-cooled }\end{array}$} \\
\hline $\begin{array}{l}\text { sity, W/ } \mathrm{cm}^{3} \\
\text { Core position }\end{array}$ & Offset & Offset & Central & offset & Centra1 \\
\hline $\begin{array}{l}\text { Turbomachine } \\
\text { position }\end{array}$ & Chordal & Chordal & Chordal & Chordal & Delta \\
\hline $\begin{array}{l}\text { No. of recupera- } \\
\text { tors }\end{array}$ & 2 & 2 & 2 & 2 & 3 \\
\hline $\begin{array}{l}\text { No. of inter- } \\
\text { coolers }\end{array}$ & -- & 2 & - & 2 & -- \\
\hline $\begin{array}{l}\text { No. of } \\
\text { precoolers }\end{array}$ & 2 & 2 & 2 & 2 & 3 \\
\hline $\begin{array}{l}\text { No. of major } \\
\text { cavities }\end{array}$ & 12 & 14 & 12 & 14 & 16 \\
\hline PCRV diam, m & 37.2 & 39.6 & 39.6 & 42.7 & 39.3 \\
\hline PCRV height, m & 35.4 & 35.4 & 35.4 & 35.4 & 35.4 \\
\hline No. of CACS units & 3 & 3 & 3 & 3 & 3 \\
\hline Design status & Conceptual & Conceptual & Conceptual & Conceptual & Conceptual \\
\hline
\end{tabular}

TABLE 4
MOTIVATING FACTORS FOR A TWO-LOOP COMMERCIAL PLANT CONFIGURATION

1. Efficient PCRV design of small diameter strongly impacts cost.

2. Simplified vessel (tendon layout eased in bottom head).

3. Intercooling can be utilized with no major impact on PCRV size. possible.

5implified gas flow paths within PCRV (pressure loss $\ngtr 12 \%$ ).

6. Ease of maintenance, since generator does not have to be moved to replace the turbomachine.

7. Spare machine approach by utility group/organization ensures high plant avallability.

8. Plant operation on one loop considered possible (impact on avai1ability and heat supply).

9. Flexibility in power range advantage for different utilities. Growth potential possible from conservatively designed power conversion equipment.

Main loop cool-down perhaps eased by duplication of turbomachines. Commercial plant can be replicated from the first-of-a-kind plant. No scaling from demo to commercial plant necessary.

Reduced development risk and cost.

all of the high voltage connections are at one end of the plant.

The 400-MW(e) non-intercooled machine (Fig. 14) has 18 compressor stages and eight turbine stages. In the 600-MW(e) machine (Fig. 15), intercooling necessitates splitting the compressor into 2 elght-staye sections, and a high-efficiency nine-stage turbine is utilized. For both machines, the rotors are of weIded construction. Welded rotors have a long successful history in Europe for both gas and steam turbines. The stress levels in the turbine blades are commensurate with a life of $280,000 \mathrm{~h}$ (i.e., 40 years at $80 \%$ capacity factor). For the turbine inlet temperature of $850^{\circ} \mathrm{C}$, blade cooling is not necessary, and an existing-nickel-base alloy ( IN-100), which has been used extensively in open-cycle industrial gas turbines, was selected for the turbine blading. The casing diameter for both machines is $4.0 \mathrm{~m}$, but of course, the higher helium mass flow rate for the 600-MW(e) machine results in an increased annulus flow area and larger blade heights, as shown on Table 5. The overall lengths of the 400-MW(e) (nonintercooled) and 600-MW(e) (intercooled) machines are $11.3 \mathrm{~m}$ and $15.8 \mathrm{~m}$, respectively. Since the turbomachine is installed inside the reactor vessel, rotor burst protection is incorporated in the machine design in the form of containment rings around the compressor and turbine rotor bladed sections.

Man-access provisions are provided in the PCRV for inspection and limited maintenance work on the journal bearings, which are of the multiple, tilting pad, oil-1ubricated type. The spaces in which the bearings are located are isolated from the main cycle working fluid by shielding (purge gas from the plant helium storage system is used to give an acceptable radiological environment for man-access). The drive to the generator is from the compressor end of the turbumaline, and the thrust bearing is located external to the PCRV to facilitate inspection and maintenance and to limit the number of oil-systems in the primary system to a minimum. Diagnostic condition monitoring, in-situ inspection, and maintenance features are designed into the turbomachine system (23).

For a single-shaft helium turbomachine (with a rotational speed of $3600 \mathrm{rpm}$ ) in the power range of 


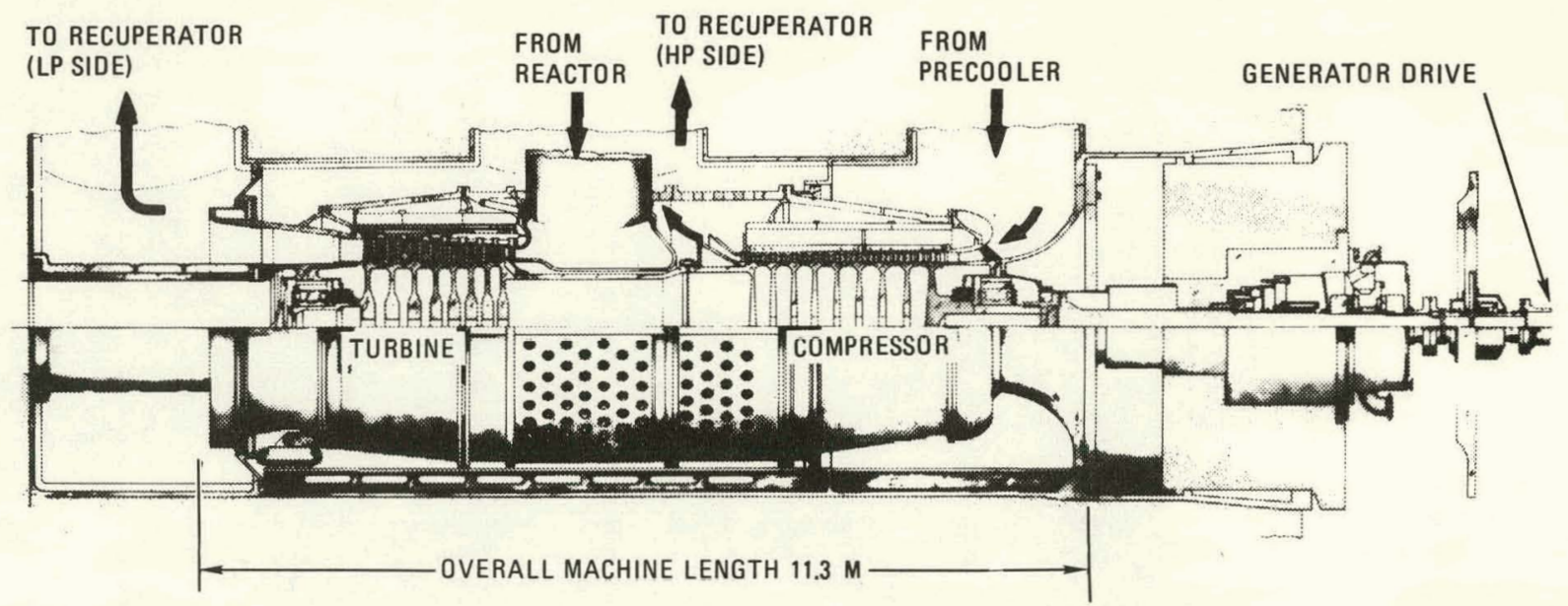

Fig.14 400-MW(e) non-intercooled turbomachine for HTGR-GT plant

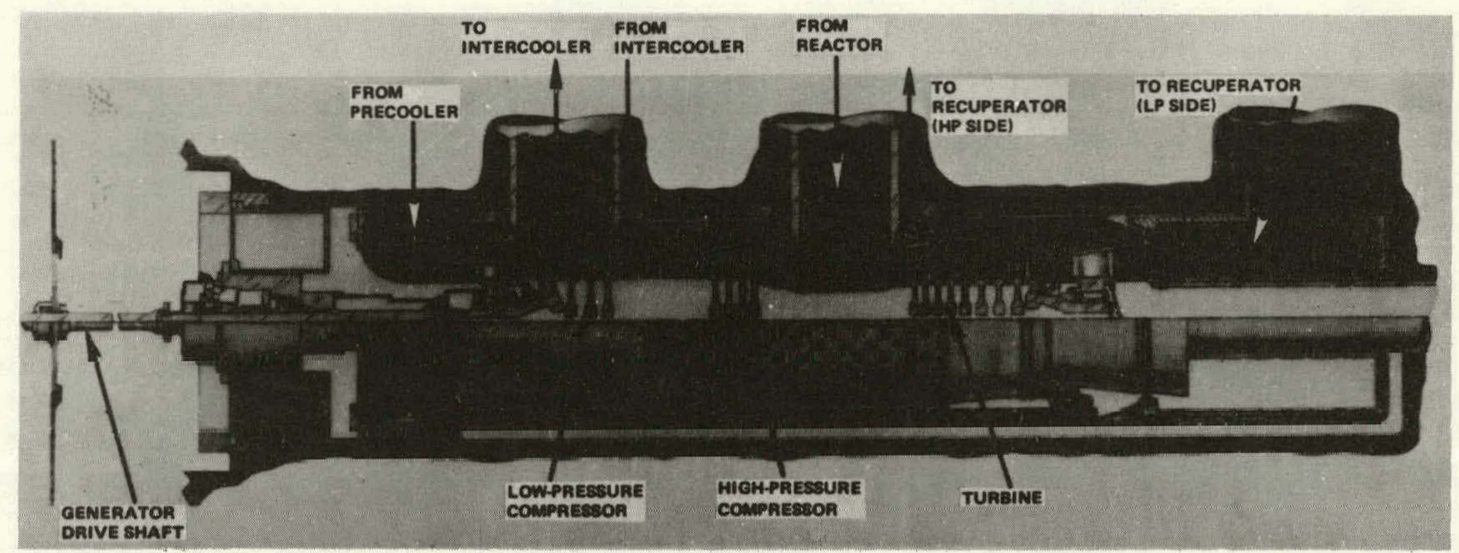

Fig. 15 600-MW(e) intercooled turbomachine for HTGR-GT plant

400 to $600 \mathrm{MW}(\mathrm{e})$, the rotating section is compact and is substantially smaller than an equivalent airbreathing machine because of the high degree of pressurization (particularly at the turbine exit) and the high specific power associated with the helium working fluid. The external dimensions of the helium turbomachines discussed in this paper are, in fact, quite similar to those of an existing air-breathing, advanced, open-cycle industrial gas turbine in the 70 to $100 \mathrm{MW}(\mathrm{e})$ range. The fact that the helium turbine (particularly the rotor assembly and casings) is comparable in size with existing machines substantiates the claim that conventional fabrication methods and facilities can be used.

The aforementioned helium turbomachine design activities have been done in support of the HTGR-GT plant for the U.S. market $(60 \mathrm{~Hz}$ system); however, it should be poinced out that a tormidable eftort has also been expended in Europe for the HHT plant (10), and details of the turbomachine for this $50-\mathrm{Hz}$ system have been sepurled in Refs. (24-26).

Heat Exchangers

$$
\text { While details of the heat exchangers have been }
$$

discussed previously (27), it is meaningful to discuss them briefly in the context of this paper, since they are large components and have a significant influence on the integrated primary system. The combined effects of size constraint (integration in the PCRV side-wall cavities), in-service inspection (ISI), in-situ repair, and maintenance and fabrication considerations have a significant effect on the choice of surface geometry, flow configuration, and mechanical design. In the conceptual design phase of the HTGR-GT plant, the thermalhydraulic sizing and analysis of the heat exchangers was performed by General Atomic, and the mechanical design work was done by Combustion Engineering. In support of the plant configuration studies, heat exchanger conceptual designs were done for units with PCL ratings of 400,500 , and $600 \mathrm{MW}(\mathrm{e})$ for both intercooled and non-intercooled types. To span the above power range and to illustrate the major differences between the two cycle types only, the exchangers for the 400-MW(e) (non-intercooled) and $600-M W(e)$ (intercooled) variants are discussed in this paper. The salient features of the recuperators, precoolers, and intercooler are given on Table 6 . 
TABLE 5

DETAILS OF HTGR-GT PLANT TURBOMACHINE DESIGNS

\begin{tabular}{|c|c|c|}
\hline Turbomachine Rating, MW(e) & 400 & 600 \\
\hline Machine type & Non-intercooled & Intercooled \\
\hline Machine arrangement & Single-shaft & Single-shaft \\
\hline Frequency, $\mathrm{Hz}$ & & 60 \\
\hline No. of turbine inlet ducts & $\begin{array}{r}1 \\
850^{1}\end{array}$ & $\begin{array}{r}1 \\
850\end{array}$ \\
\hline $\begin{array}{l}\text { Turbine inlet temp, }{ }^{\circ} \mathrm{C} \\
\text { Compressor pressure ratio }\end{array}$ & $\begin{array}{l}850 \\
2.50\end{array}$ & $3.0 \quad \begin{array}{l}850 \\
(1.73 / 1.73)\end{array}$ \\
\hline No. of compressor stages & 18 & $8+8$ \\
\hline Max compressor tip diam, m & 1.83 & 2.18 \\
\hline Blade height, $\mathrm{mm}(\min / \max )$ & $80.0 / 125.7$ & $76.2 / 165.1$ \\
\hline $\begin{array}{l}\text { Compressor adiabatic } \\
\text { efficiency (across } \\
\text { blading), \% }\end{array}$ & 89.8 & $90.8 \mathrm{LP} / 90.2 \mathrm{HP}$ \\
\hline No. of turbine stages & 8 & 9 \\
\hline Max turbine tip diam, $m$ & 2.18 & 2.40 \\
\hline Blade height, $\operatorname{mm}(\min / \max )$ & $125.7 / 297.2$ & $165.1 / 393.7$ \\
\hline $\begin{array}{l}\text { Turbine isentropic effic. } \\
\text { (across blading), \% }\end{array}$ & 91.8 & 92.2 \\
\hline Blading life, h & 280,000 & 280,000 \\
\hline Blade cooling & No & alloy $\frac{\text { No }}{\mathrm{IN}-100}$ \\
\hline $\begin{array}{l}\text { Turbine blade material } \\
\text { Generator drive end }\end{array}$ & \multicolumn{2}{|c|}{$\begin{array}{c}\text { Nickel-base alloy, } \mathrm{IN}-100 \\
\text { Compressor }\end{array}$} \\
\hline $\begin{array}{l}\text { Rotor burst shield } \\
\text { Thrust bearing position }\end{array}$ & \multicolumn{2}{|c|}{$\begin{array}{c}\text { Yes, integral part of machine structure } \\
\text { External to PCRV }\end{array}$} \\
\hline No. of journal bearings & 2 & $\begin{array}{c}2 \\
y^{2}\end{array}$ \\
\hline Journal bearing man access & Yes & Yes \\
\hline Type of rotor construction & Welded rotor & Welded rotor \\
\hline Machine casing diam, $m$ & 4.0 & 4.0 \\
\hline Machine length, m & 11.3 & $\begin{aligned} 15.8 & \end{aligned}$ \\
\hline Machine weight, kg & 276,770 & 317,600 \\
\hline Design technology base & Large industrial & open-cycle gas turbines \\
\hline
\end{tabular}

The heat exchanger types selected for the HTGRGT plant conceptual design have a sound technology base, and in this regard can be considered to be conservative. The helium-to-helium recuperator concept (shown on Fig. 16) remains unchanged from that reported previously in Ref. (28), namely, a straighttube, counterflow arrangement, with an overall assembly made up from a multiplicity of contiguous hexagonal modules. In the case of the helium-to-water exchangers (precooler and intercooler), an extensive study led to a change in concept from the previous straight-tube, counterflow, modular approach (28), to a multipass cross-counterflow helical bundle configuration as typified in Fig. 17. The helical approach has the advantages of higher water velocity, considerably fewer tubes, larger tube diameters, more straightforward headering, and better ISI accessibility than the straight-tube counterflow variant. The recuperator, precooler, and intercooler assemblies are well integrated in the PCRV, and the interfaces have received attention during the conceptual design phase to ensure the viability of the selected mechanical design approaches. The axial counterflow recuperator (embodying tubes of small diameter) bears a close resemblance to units that have operated trouble-free for over half a million hours in the European fossil-fired CCGT plants. The multipass cross-counterflow helical bundle approach selected for the precooler and intercooler has been used extensively for steam generators in gas-cooled

TABLE 6

DETAILS OF HTGR-GT PLANT HEAT EXCHANGER DESIGNS

\begin{tabular}{|c|c|c|c|c|c|}
\hline $\begin{array}{l}\text { PCL Rating, } \\
\mathrm{MW}(\mathrm{e})\end{array}$ & \multicolumn{2}{|c|}{$\begin{array}{c}400 \text { MW(e) } \\
\text { Non-intercooled }\end{array}$} & \multicolumn{3}{|c|}{$\begin{array}{r}600 \mathrm{MW}(\mathrm{e}) \\
\text { Intercooled }\end{array}$} \\
\hline Exchanger & Recuperator & Precooler & Recuperator & Precooler & Intercooler \\
\hline $\begin{array}{l}\text { Exchanger } \\
\text { configuration }\end{array}$ & Straight tube & $\begin{array}{l}\text { Multipass } \\
\text { cross } \\
\text { counter- } \\
\text { flow } \\
\text { Helical }\end{array}$ & Straight tube & \multicolumn{2}{|c|}{$\begin{array}{l}\text { Multipass cross } \\
\text { counterflow }\end{array}$} \\
\hline Heat duty/unit, MW(t) & $\begin{array}{l}\text { modular } \\
918\end{array}$ & $\begin{array}{l}\text { bundle } \\
581\end{array}$ & $\begin{array}{l}\text { modular } \\
1253\end{array}$ & 533 & 331 \\
\hline $\begin{array}{l}\text { LMTD, }{ }^{\circ} \mathrm{C} \\
\text { Effectiveness }\end{array}$ & $\begin{array}{l}42.5 \\
0.898\end{array}$ & $\begin{array}{l}30.5 \\
0.972\end{array}$ & 44.3 & 27.3 & 19.3 \\
\hline Tubes per exchanger & 66,483 & 827 & $94,668^{.090}$ & 1196.961 & 1118 \\
\hline Tube o.d., mm & 11.1 & 28.6 & 11.1 & 28.6 & $\begin{array}{r}1118 \\
28.6\end{array}$ \\
\hline Wa11 thirknese, mm & 1.1 & 2.9 & 0.8 & 2.9 & $2 . y$ \\
\hline Modules per exchanger & 83 & 1 & 161 & 1 & 1 \\
\hline Exchanger diam, m & 5.64 & 4.72 & 6.8 & 4.9 & 4.7 \\
\hline $\begin{array}{l}\text { Effective tube } \\
\text { length, m }\end{array}$ & 12.2 & 105 & 12.8 & 82.3 & 76.2 \\
\hline Effective bundle ht, & 12.2 & 12.5 & 12.8 & 13.7 & 10.97 \\
\hline Exchanger assy. $h t, m$ & 20.4 & 19.8 & 21.1 & 21.1 & 18.3 \\
\hline $\begin{array}{l}\text { Exchanger assy. wt, } \\
\text { tonnes }\end{array}$ & 726 & 435 & 998 & 490 & 363 \\
\hline $\begin{array}{l}\text { Max metal temp, }{ }^{\circ} \mathrm{C} \\
\text { Max internal } \triangle \mathrm{P}, \\
\mathrm{MPa}\end{array}$ & $\begin{array}{l}515 \\
4.62\end{array}$ & $\begin{array}{l}177 \\
1.83\end{array}$ & $\begin{array}{r}465 \\
5.08\end{array}$ & $\begin{array}{r}125 \\
1.3\end{array}$ & $\begin{array}{l}89 \\
3.2\end{array}$ \\
\hline Materials & $\begin{array}{l}\text { Ferritic } \\
21 / 4 \mathrm{Cr}-1 \mathrm{Mo}\end{array}$ & $\begin{array}{c}\text { Low-alloy } \\
1 / 2 \mathrm{Cr}\end{array}$ & $\begin{array}{l}\text { Ferritic } \\
21 / 4 \mathrm{Cr}-1 \mathrm{Mo}\end{array}$ & \multicolumn{2}{|c|}{ Low alloy, $1 / 2 \mathrm{Cr}$} \\
\hline ISI/repair level & Module & $\begin{array}{c}\text { Individual } \\
\text { tubes }\end{array}$ & Module & \multicolumn{2}{|c|}{ Individual tubes } \\
\hline Assembly location & $\begin{array}{l}\text { Factory/ } \\
\text { optional }\end{array}$ & Factory & $\begin{array}{l}\text { Factory/ } \\
\text { optional }\end{array}$ & \multicolumn{2}{|c|}{ Factory } \\
\hline $\begin{array}{l}\text { Transportation mode } \\
\text { ASME code class }\end{array}$ & $\begin{array}{l}\text { Barge } \\
\text { Section VIII }\end{array}$ & \begin{tabular}{|l|} 
Barge \\
Section VIII
\end{tabular} & $\begin{array}{l}\text { Rarge } \\
\text { Section VIII }\end{array}$ & \multicolumn{2}{|c|}{$\begin{array}{c}\text { Barge } \\
\text { Section VIII }\end{array}$} \\
\hline $\begin{array}{l}\text { Design status } \\
\text { Technology status }\end{array}$ & \multicolumn{5}{|c|}{$\begin{array}{c}\text { Conceptual } \\
\text { State-of-the-art-technology }\end{array}$} \\
\hline
\end{tabular}




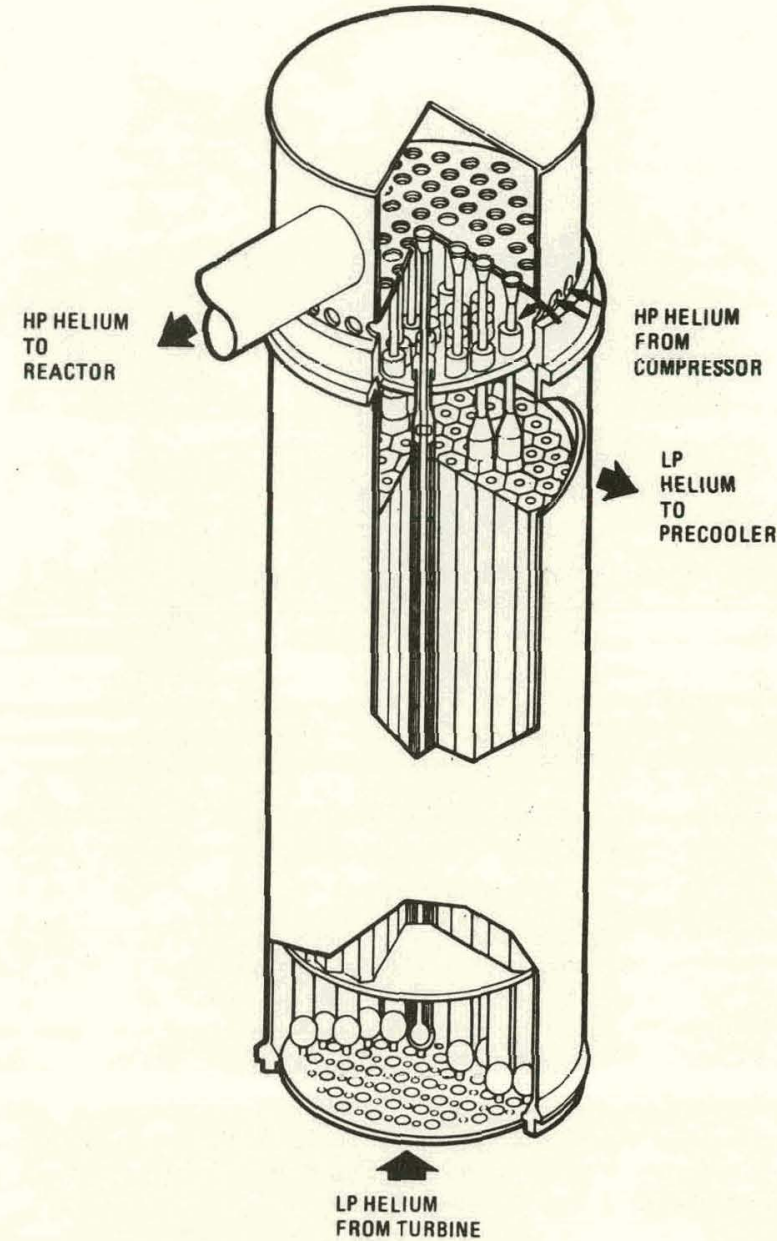

Fig.16 Straight-tube, modular, counterflow recuperator concept for HTGR plant

reactors. Thus, in adopting the aforementioned conservative design approach, it can be stated that the exchanger design types selected for the HTGR-GT plant have a proven background in the utility powergenerating industry.

Annther obvious issue related to the size and weight of the heat exchangers is the technology for handling, transporting, and installing the units in the reactor vessel. It has been shown (27) that the heat exchangers for the HTGR-GT are, in fact, no longer or heavier than units being built for contemporary steam plants, and that existing and proven methods of handling and transportation are indeed applicable.

For a long-term program such as the HTGR-GI, there is an obvious incentive to maintain the competitiveness of the plant by utilizing technology advancements in a prudent manner. Improvements in the heat exchangers will be continually sought, such as the adoption of advanced surface geometries, and the obvious goals that will be addressed in the future include (1) increased reliability/ availability, (2) cost reduction, (3) size reduction, and (4) improved ISI capability and maintenance approaches.

The aforementioned heat exchanger design acti- vities have been pursued in support of the HTGR-GT plant for the U.S. market; however, it should be pointed out that a formidable effort has also been expended in Europe for the HHT plant and details of these heat exchangers have been reported in Ref. (29).

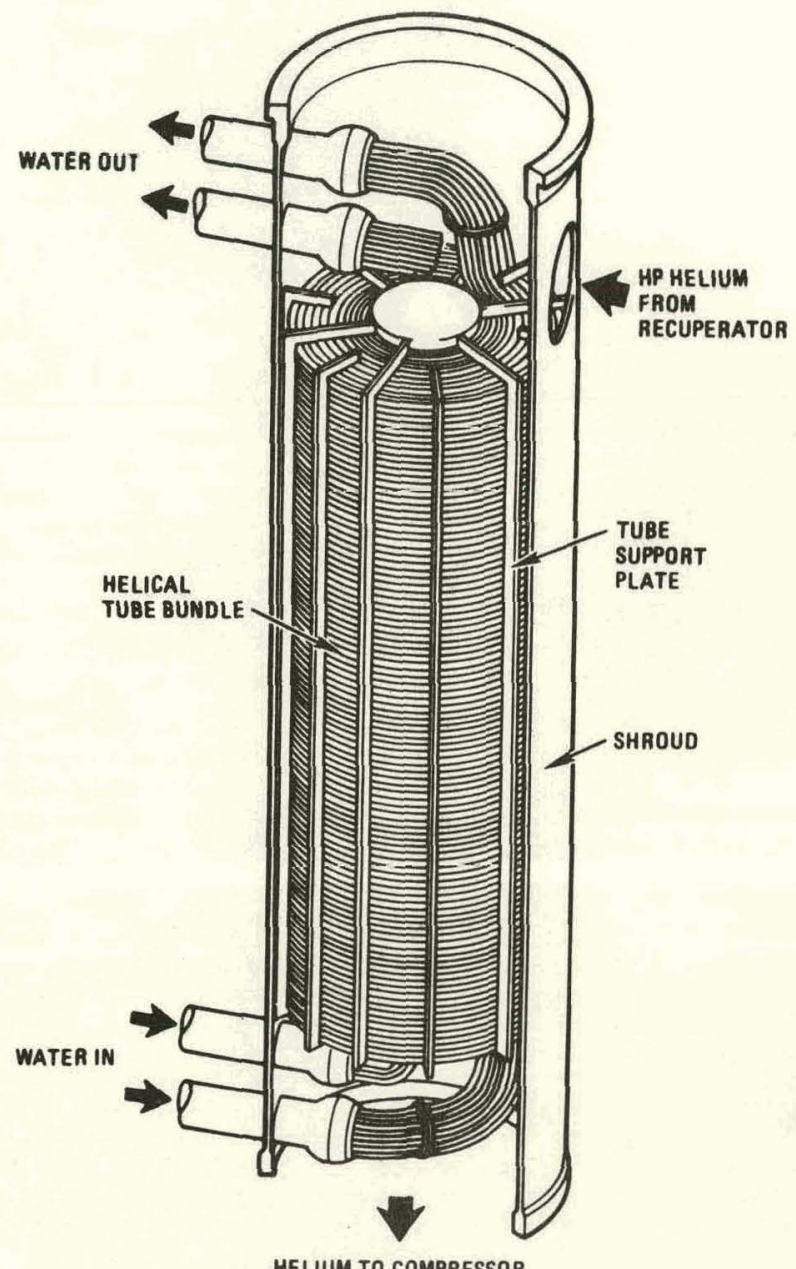

Fig.17 Helical-bundle, cross-counterflow, helium-towater heat exchanger concept (precooler and intercooler) for HTGR-GT plant

\section{BALANCE OF PLANT DESIGN}

The main point of this paper has been a discussion of the reactor turbine system (RTS) for differing power plant concepts. In addition to the RTS, which is integrated in the reactor vesse1, an important task in the design process is the establishment of the overall plant configuration, and this essentially involves the design of all the balance of plant equipment and buildings. Since this is a comprehensive task and the subject of a forthcoming paper, balance of plant design will only be highlighted in this paper, but the importance of the task should be noted. since a significant percentage of the overall plant cost is associated with the balance of plant items. In 
addition, many of the plant operational requirements, such as service systems, purification trains, refueling schemes, and on-site maintenance facilities, strongly impact the balance of plant features and economics.

Details of the overall plant plot plan for the three-loop non-intercooled plant have been discussed previously (23), so only the recent work associated with the two-loop variant will be mentioned here. As shown on Fig. 18, a reactor containment building (RCB) encloses the PCRV, and while the configuration illustrated is in a conceptual stage for the $2 \times 600$ MW(e) intercooled plant variant, it can be considered representative for the HTGR-GT plant. The secondary containment building and the PCRV incorporate safety features that limit loss of primary coolant and minimize damage in the event of failures in the turbomachine, shaft seals, heat exchangers, generator, or PCRV cavity closures.

A significant change from previous plant conceptual designs involves the utilization of all watercooled generators of the type that have been extensively used in Eurnpe for many years. The former hydrogen-cooled generator involved installation in local generator cells (which increased the complexity and cost of the RCB) to prevent the possiblity of a hydrogen explosion within the containment building in the event of a gas leakage from the generator internals. As can be seen from Fig. 18, a simpler concept is now proposed with the generator located within the containment building. This eliminates the concern over a secondary containment rotating seal penetration. A tentative plant arrangement concept for a two-1oop plant is shown on Fig. 19. This scheme illustrates the general layout of the various buildings, and indepth studies are currently underway by the architect/ engineer to further define the balance of plant facilities to satisfy all of the plant requirements.

\section{SUMMARY}

The work reported in this paper is only one part of the widespread international efforts to combine the gas turbine and nuclear energy. The benefits of the HTGR-GT plant are such that the worldwide efforts to bring it into use should increase rapidly. It is projected that with a dedicated effort the demonstration plant could be introduced into commercial utility service in the late $1990 \mathrm{~s}$, and the first commercial plant (essentially replicated from the demo plant) could be on-line around the turn of the century. For the next generation of nuclear power plants, the dominant criteria in all design endeavors is to establich unquestiunable safecy teatures. The HTGR with its graphite-moderated core, single-phase gaseous working fluid, and integration of the equipment within a PCRV offers unprecedented safety characteristics. In addition to this vital element, the prospective advantages of the HTGR-GT to utilities include plant simplification, improved economics, and siting flexibility.

The work reported in this paper has out lined design-related studies which are in progress and directed towards the selection of a commercial plant reference design. A companion paper (17) has addressed systems-related studies leading to the selection of ntimized parameters fus minlmum power generating cost. As discussed, a decision has been made to proceed with the design of a two-loop commercial plant configuration. This paper presents design-related studies which are important to deciding on the definitiun of two vital HTGR-GT features: (1) rating of the PCLs

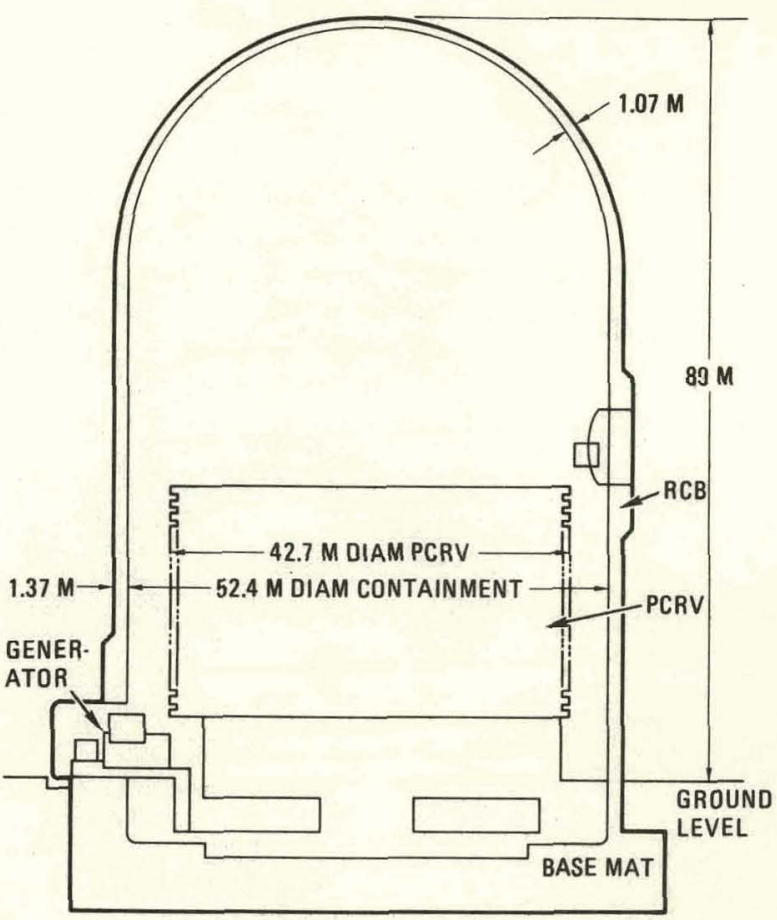

Fig. 18 Elevation view through RCB for two-loop HTGRGT plant

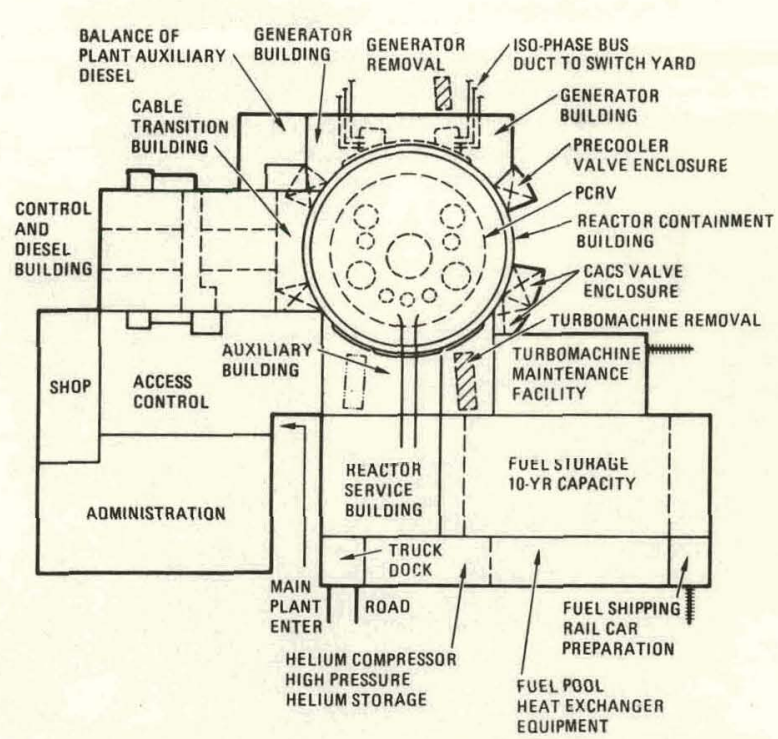

Fig.19 Tentative overall arrangement for two-loop HTGR-GT power plant

and (2) the choice of intercooled or non-intercooled cycle. These decisions will be made in 1979, and the definition of the reference commercial plant concept will be presented in a future paper. 


\section{ACKNOWLEDGEMENTS}

Appreciation is hereby expressed by the authors to the management of General Atomic Company for permission to publish this paper. Work on the HTGR-GT plant has been supported by the U.S. Department of Energy under Contract DE-AT03-76SF70046, and by a dedicated group of electric utility companies. The contribution of. Hans Amtmann of General Atomic is gratefully acknowledged. The authors wish to acknowledge work done by United Technologies Corporation, Combustion Engineering, and the European HHT Project.

\section{REFERENCES}

1 Keller, C., and Schmidt, D., "Industrial Closed-Cycle Gas Turbines for Conventional and Nuclear Fue1," ASME Paper No. 67-GT-10, 1967. 2 Bammert, K., "A General Review of ClosedCycle Cas Turbines Using Fossil, Nuclear, and Solar Energy," Thiemig Paperback, Vol. 57, Munich, September, 1975.

3 McDonald, C.F., "The Closed-Cycle Gas Turbine - Present and Future Prospectives for Fossil and Nuclear Heat Sources," ASME Paper No. 78-GT-102, 1978.

4 McDonald, C.F., and Krase, J.M., "Nuclear Gas Turbine Power Plant Activities in the United States," ASME Paper No. 77-JPGC/GT-5, 1977.

5 Goodjohn, A.J., and Law, S.H., "GT-HTGR - A Total Energy Utilization Option," AIAA/IEEE Conference on New Options in Energy Technology, San Francisco, California, August 2-4, 1977.

6 MeDonald, C.F., "The Closed-Cycle Gas Turbine - A Proven Cogeneration Plant Adaptable to Fossil, Nuclear, and Solar Heat Sources," Conference on Energy Conservation, Sponsored by U.S. Department of Energy, Milan, Italy, March 26-29, 1979.

7 Frutschi, H.U., "The Relationship of Power and Heat Production with Closed-Cycle Gas Turbines," ASME Paper 79-GT-103, 1979.

8 McDonald, C.F., "Large Closed-Cycle Gas

Turbine Plant," Lecture Series on Closed-Cycle Gas

Turbines at the Von Karman Institute for Fluid Dynamics, Sponsored by North Atlantic Treaty Organization. Brussels, Belgium, May 9-13, 1977.

9 "Technology Assessment of the Gas Turbine High-Temperature Gas-Cooled (Helium) Reactor," EPRI NR-805, Project 900, Interim Report, Electric Power Research Institute, June 1978.

10 Arndt, E., et a1, "HHT-Memnnstration Plant," paper presented at European Nuclear Conference. Hamburg, Federal Republic of Germany, May 6-11, 1979 .

11 McDonald, C.F., et al., "Primary System Design Studies for Advanced Direct-Cycle Nuclear Gas Turbine Plant," ASME Paper No. 77-GT-25, 1977.

12 Keller, C., "Forty Years of Experience on Closed-Cycle Gas Turbines," Annals of Nuclear Energy, Vo1. 5, No. 8-10, 1978, pp. 405-422.

13 Bammert, K., and Deuster, G,, "Layout and Present Status of the Closed-Cycle Helium Turbine oberhausen," ASME Paper No. 74-GT-132, 1974.

14 Zenker, P., "The Oberhausen $50 \mathrm{MW}(\mathrm{e})$ Helium Turbine Plant," Combustion, Vol. 47, No. 10, Oct. 1976 , pp. 21-25.

15 Weber, D., "Helium Turbine Explores Future Nuclear Application," Energy International, Vol. 15, No. 4, Apt 11. 1978, pp. 47-50.

16 Noack, G., et al., "Significance of the Helium Turbine Plant at Oberhausen (EVO) and of the High Temperature Test Facility at Jülich (Huv) for the Development of the HTGR Direct-Cycle System (HHT)," Symposium on Gas-Cooled Reactors with Emphasis on Advanced Systems, Jülich, Federal Republic of Germany, October 1975, Vol. II, IAEA, Vienna, Austria, May 1976, pp. 189-200.

17 Kammerze11, L.L., "HTGR-GT Systems Optimization Studies," 25th ASME International Gas Turbine Conference, New Orleans, Louisiana, March 1980, to be presented.

18 McDonald, C.F., "The Nuclear Closed-Cycle Gas Turbine (GT-HTGR) - A Itility Power Plant for the Ycar 2000," AIAA Paper 79-0191, 1919.

19 Adams, R.G., and Boenig, F.H., "The Design of the Turbomachinery for the Gas Turbine HTGR Power P1ant," ASME Paper No. 77-GT-38, 1977.

20 Adams, R.G., et al., "Bearing Compartment Seal Systems for Turbomachinery in Direct-Cycle HTGR Power P1ants," ASME Paper No. 78-GT-38, 1978.

21 McDonald, C.F., and Smith, M.J., "Turbomachinery Design Considerations for the Nuclear HTGR-GT Power Plant," 25th ASME International Gas Turbine Conference, New Orleans, Louisiana, March 1980 , to be presented.

22 de Biasi, D., "FT-50 Design Shortcut to 1980 Technology," Gas Turbine World, Nov. 1975, pp. 9-15.

23 McDonald, C.F., and Paget, J.A., "Maintenance Considerations in the Design of the Direct-Cycle Nuclear Gas Turbine Power Plant," ASME Paper No. 79-GT-116,. 1979.

24 Haselbacher, H., and Eiermann, A., "Development of Helium Gas Turbine Systems in the Nuclear Fie1d," ASME Paper No. 74-GT-123, 1974. 25 Haselbacher, H., et al., "HHT Helium Turbine and the HHV Plant," Nuclex 78, Base1, Switzerland, October 3-7, 1978 (Paper No. A4/21).

26 Haselbacher, H., "Closed-Cycle Gas Turbines tor HTR Nuclear Power Plants and LNG Regasification Plants," Brown Boveri Revue, Vo1. 66, No. 2, Feb. 1979, pp. $120-129$.

27 Van Hagan, T.H., McDonald, C.F., and Creek, R.B., "Heat Exchanger Designs for Gas Turbine HTGR Power Plant," ASME Paper No. 79-WA/GT-2, 1979. 28 McDonald, C.F., Van Hagan, T.H., and Vepa, K., "Heat Exchanger Design Considerations for Gas Turbine HTGR Power Plant," ASME Journal of Engineering for Power, Vo1. 99, April 1977, pp. 237-245.

29 Naegelin, R., et a1., "Heat Exchangers for HHT Plants," Nuclex 78, Base1, Switzerland, October $3-7,1978$, (Paper No. A4/16). 


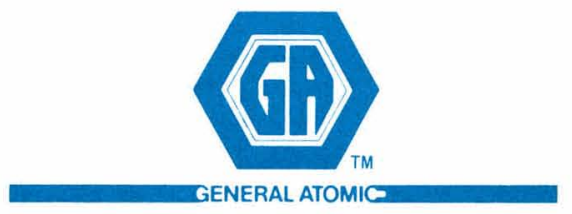

GENERAL ATOMIC COMPANY

P. O. BOX 81608

SAN DIEGO, CALIFORNIA 92138 